\title{
cRGD-installed polymeric micelles loading platinum anticancer drugs enable cooperative treatment against lymph node metastasis
}

Jun Makino $^{1}$, Horacio Cabral ${ }^{2 *}$, Yutaka Miura ${ }^{1}, Y u$ Matsumoto ${ }^{1}$, Ming Wang ${ }^{3}$, Hiroaki Kinoh ${ }^{4}$, Yuki Mochida $^{4}$, Nobuhiro Nishiyama ${ }^{5}$ and Kazunori Kataoka ${ }^{1,2,3,4^{*}}$

${ }^{1}$ Center for Disease Biology and Integrative Medicine, Graduate School of Medicine, The University of Tokyo, 7-3-1 Hongo, Bunkyo-ku, Tokyo 113-0033, Japan.

${ }^{2}$ Department of Bioengineering, Graduate School of Engineering, The University of Tokyo, 7-3-1 Hongo, Bunkyo-ku, Tokyo 113-8656, Japan.

${ }^{3}$ Department of Materials Engineering, Graduate School of Engineering, The University of Tokyo, 7-3-1 Hongo, Bunkyo-ku, Tokyo 113-8656, Japan.

${ }^{4}$ The Innovation Center of Nanomedicine, 66-20 Horikawa-cho, Saiwai-ku, Kawasaki 212-0013, Japan.

${ }^{5}$ Polymer Chemistry Division, Chemical Resources Laboratory, Tokyo Institute of Technology, R1-11, 4259 Nagatsuta, Midori-ku, Yokohama 226-8503, Japan.

*Corresponding author

Kazunori Kataoka, PhD

E-mail: kataoka@bmw.t.u-tokyo.ac.jp

Horacio Cabral, $\mathrm{PhD}$

E-mail: horacio@bmw.t.u-tokyo.ac.jp 


\begin{abstract}
Lymph node metastasis (LNM) is correlated with decreased survival, indicating high tumor malignancy and being a potential source for subsequent fatal metastases. Targeted therapies inhibiting the formation of LNM, while eliminating established metastatic foci, could provide synergistic effects by reducing the incidence and growth of metastasis. Based on the inhibitory activity of cRGD peptide against the development of metastasis, and the LNM targeting ability of systemically injected drug-loaded polymeric micelles, herein, we studied the capability of cRGD-installed polymeric micelles incorporating the platinum anticancer drug (1,2-diaminocylohexane)platinum(II) (DACHPt) for cooperatively inhibiting the formation and progression of LNM. As cRGD-installed DACHPt-loaded micelles (cRGD-DACHPt/m) presented similar size, drug loading and surface charge to non-conjugated micelles (MeO-DACHPt $/ \mathrm{m})$, the differences in the biological performance of the micelles were endorsed to the effect of the ligand. In a syngeneic melanoma model, both $\mathrm{MeO}-\mathrm{DACHPt} / \mathrm{m}$ and $\mathrm{cRGD}-\mathrm{DACHPt} / \mathrm{m}$ showed comparable antitumor activity against the primary tumors and the established metastatic foci in lymph nodes. However, cRGD-DACHPt/m significantly enhanced the efficacy against LNM draining from primary tumors through the effective inhibition of the spreading of cancer cells. This improved inhibition was associated with the ability of cRGD-DACHPt/m to reduce the migration of melanoma cells, which was higher than that of MeO-DACHPt/m, free cRGD and their combination. These results support our strategy of using cRGD-installed micelles for attaining cooperative therapies against LNM exploiting the inhibitory function of the peptide and the cytotoxic effect of the micelles.
\end{abstract}




\section{Introduction}

Cancer metastasis is one of the most threatening aspects in cancer, representing more than $90 \%$ of cancer-related deaths [1]. Particularly, metastasis to regional lymph nodes is clinically significant, as it is the first site of metastasis in several types of cancer, including melanoma, breast, gastric, colon, prostate, and head and neck cancer, being associated with poor prognosis [2-6]. Besides indicating a more malignant tumor biology, lymph node metastasis (LNM) are also the source for subsequent fatal metastases. Indeed, recent pre-clinical and clinical studies have shown that tumor cells spread more to systemic sites from LNM than from primary tumors, probably supported by the microenvironment of lymph nodes [7-10]. Therefore, therapeutic approaches capable of effectively eradicating LNM could have a radical impact on the care of cancer by decreasing the incidence of metastases to distant organs and improving overall survival.

Several therapeutic strategies have been considered for treating LNM, including the inhibition of LNM development or the elimination of already developed LNM. Accordingly, lymphangiogenesis inhibitors have been widely studied for reducing the formation of LNM through the decreased connection of primary tumors with lymph nodes, showing less distant metastases and extended survival in various tumor models [11], though their efficacy is limited against established tumors [12-14]. On the other hand, LNM are currently treated by radiotherapy [15-17], or by intralymphatic, or locally [18] or systemically administered chemotherapy [19-22], which present serious issues regarding toxicity, efficacy and residual disease, jeopardizing survival and QOL of patients [23]. Thus, targeted therapies that can simultaneously inhibit the formation of LNM and treat both primary tumors and LNM, regardless of their anatomical position, could synergistically increase their effectiveness and dramatically improve therapeutic outcomes.

Nanomedicines have the potential for achieving such synchronized targeted therapies by including inhibitory and cytotoxic functions in their architecture. Nanomedicines, such as liposomes 
[24.25], polymer-drug conjugates [26,27], self-assembled polymeric nanostructures [28,29], nanoparticles [30-32], and dendrimers [33,34],have demonstrated capability for improving efficacy and reducing side effects. Among them, polymeric micelles having a drug-loaded hydrophobic core surrounded by a poly(ethylene glycol) (PEG) hydrophilic shell have shown outstanding features for selectively delivering drugs to solid tumors, including their relatively small size, high drug loading capacity and prolonged blood circulation [29], and several micelle formulations incorporating anticancer drugs are showing improved survival and reduced side effects in various clinical trials [35]. By using polymeric micelles conjugating the parent compound of the anticancer drug oxaliplatin, i.e. (1,2-diaminocyclohexane)platinum(II) (DACHPt), via polymer-metal complex formation with poly(ethylene glycol)-b-poly(L-glutamic acid) (PEG-b-P(Glu)) copolymer [36,37] (Figure 1A), we have recently demonstrated that it is also possible to target and treat LNM through systemic administration of micelles [36,37]. Thus, herein, we evaluated the cooperative effect of including a metastasis inhibitory function to the cytotoxic capability of DACHPt-loaded micelles (DACHPt/m) through the conjugation of cyclic Arg-Gly-Asp (cRGD) peptides on the micelles' surface (Figure 1B), since cRGD peptide has shown to reduce the development of metastasis by inhibiting angiogenesis or integrin-dependent metastatic processes [38-40]. cRGD peptide has been used to improve the targeting of nanomedicines by selectively binding to $\alpha_{\mathrm{v}} \beta_{3} / \alpha_{\mathrm{v}} \beta_{5}$ integrins overexpressed on cancer cells and neovasculature [41-43], and our previous report revealed that cRGD-installed DACHPt/m (cRGD-DACHPt/m) enhanced drug delivery efficiency in a glioblastoma tumor model overexpressing $\alpha_{\mathrm{v}} \beta_{3} / \alpha_{\mathrm{v}} \beta_{5}$ integrins [44]. In current study, the in vivo inhibitory and antitumor activities of cRGD-DACHPt $/ \mathrm{m}$ were assessed in a syngeneic melanoma model, which allow us to construct a model having only metastases by directly resecting the primary tumor in the footpad of mice, and compared to that of non-conjugated micelles (MeO-DACHPt/m) to elucidate the conditions for their efficacy enhancement. 
A
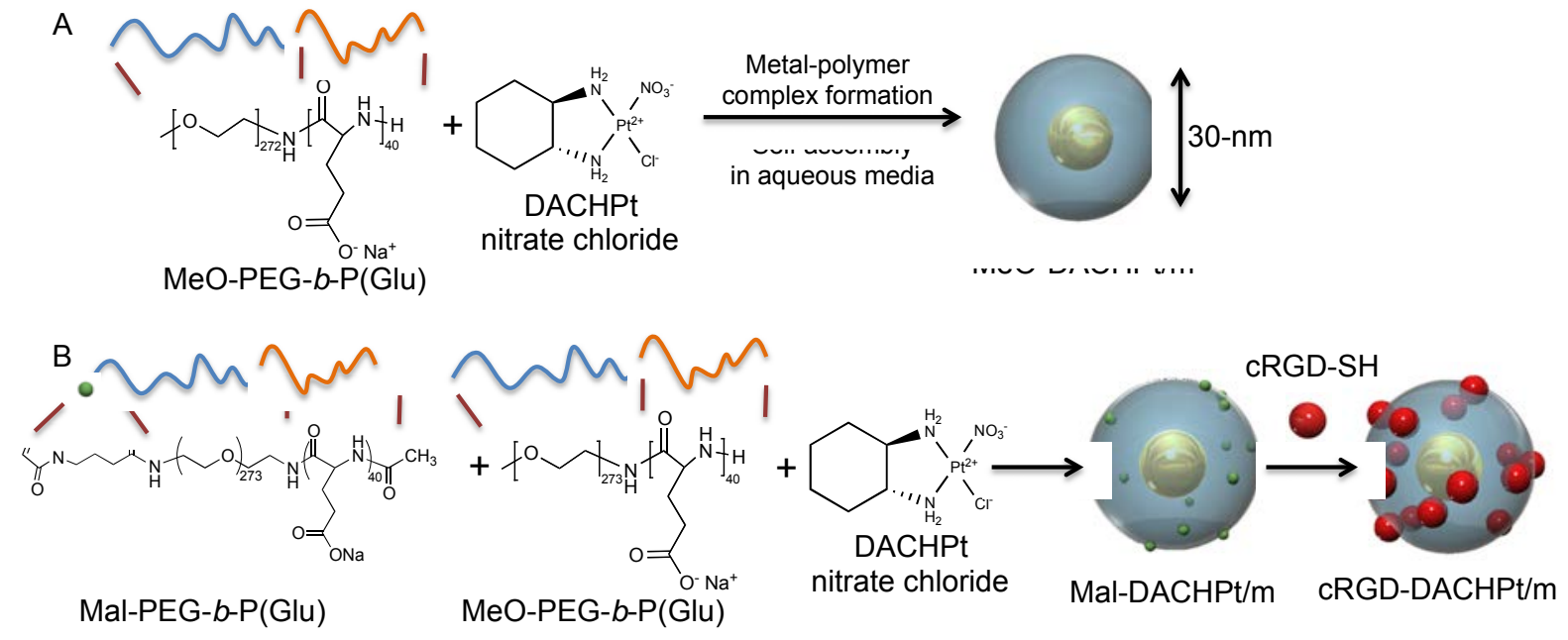

Figure 1. Preparation of DACHPt-loaded micelles without ligands (MeO-DACHPt/m) and cRGD-installed DACHPt-loaded micelles (cRGD/DACHPt/m). A. MeO-DACHPt $/ \mathrm{m}$ self-assembled by the metal-polymer complex formation of DACHPt and the carboxylate moieties in methoxy-poly(ethylene glycol)-b-poly(L-glutamic acid) [MeO-PEG-b-P(Glu)] copolymer. The diameter of the micelles is approximately $30-\mathrm{nm}$. B. Maleimide-linked DACHPt/m were prepared as precursor micelles by mixing maleimide-PEG- $b$-P(Glu) [Mal-PEG- $b-\mathrm{P}(\mathrm{Glu})]$ and MeO-PEG- $b$-P(Glu) copolymers at a 1:3 molar ratio, followed by the metal-polymer complex formation with DACHPt. Cyclo[RGDfK(CX-)] [cRGD] was then added into the solution to obtain cRGD-DACHPt $/ \mathrm{m}$. The amount of cRGD peptide conjugated on the surface was fixed at $20 \%$ of the PEG chains.

\section{Materials and Methods}

Materials

Dimethyl sulfoxide (>99\%), triethylamine (TEA, >99\%) and methanesulfonyl chloride $(\mathrm{MsCl},>99 \%)$ were purchased from Wako Pure Chemical Industries, Ltd., (Tokyo, Japan) and used after distillation over $\mathrm{CaH}_{2}$. $\alpha$-Methoxy- $\omega$-amino poly(ethylene glycol) (MeO-PEG-NH2, 12,000 g/mol, NOF Corporation, Tokyo, Japan) was purified through an ion exchange CM Sephadex C-50 
column (GE Healthcare Ltd., UK). $\alpha$-Tetrahydropyranyloxy- $\omega$-methanesulfonyl poly(ethylene glycol) (THP-PEG-Ms, 12,300 g/mol, NOF Corporation, Tokyo, Japan), $N$-carboxy anhydride of $\gamma$-benzyl L-glutamate (Chuo Kaseihin Co., Inc., Tokyo, Japan), sodium azide ( $>98 \%$, Wako Pure Chemical Industries, Ltd., Osaka, Japan), sodium hydroxide (96\%, Wako Pure Chemical Industries Ltd., Osaka, Japan), acetic anhydride (>97\%, Wako Pure Chemical Industries Ltd., Osaka, Japan), $N$-(4-maleimidobutyryloxy)sulfosuccinimide, sodium salt $\quad$ (sulfo-GMBS, $>99.0 \%, \quad$ Dojindo Laboratories, Kumamoto, Japan), palladium nanoparticles (PdNPs, obtained from Kawamura Institute of Chemical Research, Chiba, Japan), dichloro(1,2-diaminocyclohexane)platinum(II) (DACHPtCl 2 , W. C. Heraeus GmbH \& Co. KG), silver nitrate $\left(\mathrm{AgNO}_{3}, 99.999 \%\right.$, Aldrich Chemical Co., Milwaukee, WI), and other reagents were used without purification. Cyclo[RGDfK(CX-)] (cRGD peptide, $X=6$-aminocaproic acid: $\square$-Acp) was purchased from Peptide Institute Inc., Osaka, Japan. RPMI-1640 medium was bought from Sigma-Aldrich Co. (ST. Louis, MO). Fetal bovine serum (FBS) was purchased from Dainippon Sumitomo Pharma Co., Ltd. (Osaka, Japan). EGMTM-2 BulletKit $^{\mathrm{TM}}$ was purchased from Lonza Japan (Tokyo, Japan). Phosphate-buffered saline (PBS) was bought from Wako Pure Chemical Industries Ltd. (Osaka, Japan). BioCoat ${ }^{\mathrm{TM}}$ Collagen I 96-well black/clear plates were purchased from Fisher Scientific (Pittsburgh, USA). Cell Counting

Kit-8 was bought from Dojindo Laboratories (Kumamoto, Japan). Cytoselect ${ }^{\mathrm{TM}}$ 96-well Cell Migration Assay was purchased from Cell Biolabs, Inc. (San Diego, USA). Alexa 555-NHS and Alexa 647-NHS were bought from ThermoFisher Scientific (Waltham, USA).

\section{Cells and Animals}

B16F10-luc murine melanoma cell line was purchased from Xenogen (Alameda, CA). B16F10-GFP cells were purchased from Anticancer, Co. (San Diego, CA). Human Umbilical Vein Endothelial cells (HUVEC) were bought from Lonza (Tokyo, Japan). C57BL6/J mice were 
purchased from Oriental Yeast Co., Ltd. (Tokyo, Japan). All animal experiments were done under the ethical guidelines of The University of Tokyo.

Synthesis of Block Copolymers

Methoxy-poly(ethylene glycol)-b-poly(L-glutamic acid) [MeO-PEG- $b$-P(Glu); molecular weight of PEG: 12,000; degree of polymerization of glutamic acid: 40] was synthesized as previously reported [45]. Accordingly, $N$-carboxyanhydride of $\gamma$-benzyl L-glutamate (BLG-NCA) was synthesized by the Fuchs-Farthing method using triphosgene. Polymerization of BLG-NCA in dimethylformamide (DMF) was performed by initiation with the amino group of $\mathrm{CH}_{3} \mathrm{O}-\mathrm{PEG}-\mathrm{NH}_{2}$ to obtain MeO-PEG- $b$-poly( $\gamma$-benzyl L-glutamate) (MeO-PEG- $b$-PBLG). PEG- $b$-PBLG was deprotected by reaction with $0.5 \mathrm{~N} \mathrm{NaOH}$ at room temperature to prepare MeO-PEG-b-P(Glu). ${ }^{1} \mathrm{H}-\mathrm{NMR}$ measurement was performed to confirm the complete deprotection of benzyl groups from the block copolymer. Maleimide-poly(ethylene glycol)-b-poly(L-glutamic acid) [Mal-PEG-b-P(Glu)] (molecular weight of PEG: 12,000; degree of polymerization of glutamic acid: 40) was synthesized as previously reported [44]. In brief, $\mathrm{NaN}_{3}$ was added to THP-PEG-Ms to obtain $\mathrm{N}_{3}$-PEG-THP. $\mathrm{N}_{3}$-PEG-THP in methanol was mixed with aq. $\mathrm{HCl}$ to obtain $\mathrm{N}_{3}$-PEG-OH. $\mathrm{MsCl}$ solution in THF was added to the mixture of TEA and $\mathrm{N}_{3}$-PEG-OH to prepare $\mathrm{N}_{3}$-PEG-Ms. $\mathrm{N}_{3}$-PEG-NH $\mathrm{N}_{2}$ was formed by dissolving $\mathrm{N}_{3}$-PEG-Ms in $25 \%$ ammonia. Then, $\mathrm{N}_{3}-\mathrm{PEG}-\mathrm{NH}_{2}$ was used as an initiator of the ring opening polymerization of BLG-NCA similarly to MeO-PEG- $b$-P(Glu) to obtain $\mathrm{N}_{3}$-PEG- $b$-PBLG. $\quad \mathrm{N}_{3}$-PEG- $b$-PBLG was deprotected with $0.5 \mathrm{~N}$ $\mathrm{NaOH}$ at room temperature to obtain $\mathrm{N}_{3}$-PEG- $b$-P(Glu). Then, $\mathrm{N}_{3}$-PEG- $b$-P(Glu) was reacted with PdNPs, followed by sulfo-GMBS to synthesize Mal-PEG- $b$-P(Glu). To prepare fluorescent labeled MeO-PEG-b-P(Glu) or Mal-PEG-b-P(Glu), polymers and Alexa 555-NHS or Alexa 647-NHS were mixed in DMSO for $3 \mathrm{~h}$ (1:1 molar eq.). Then, the polymers were dialyzed against water and further 
purified by using prepacked PD MidiTrap G-10 gravity columns (GE Healthcare Life Sciences; Pittsburgh, USA). Resulting $10 \% \mathrm{~mol} / \mathrm{mol}$ of the copolymers were fluorescently labeled.

Preparation of DACHPt-loaded Micelles (MeO-DACHPt/m)

MeO-DACHPt/m were prepared with MeO-PEG- $b$-P(Glu) as previously described [45]. $\mathrm{DACHPtCl}_{2}(5 \mathrm{mM})$ and $\mathrm{AgNO}_{3}\left(\left[\mathrm{AgNO}_{3}\right] /[\mathrm{DACHPt}]=1\right)$ were mixed in distilled water, and kept in the dark at $25{ }^{\circ} \mathrm{C}$ for $24 \mathrm{~h}$ to obtain DACHPt nitrate chloride. Centrifugation of the solution was done to remove $\mathrm{AgCl}$ precipitates. The supernatant was filtrated by using a $0.22-\mu \mathrm{m}$ filter. MeO-PEG- $b-\mathrm{P}(\mathrm{Glu})$ was mixed with DACHPt nitrate chloride solution ([Glu $]=5 \mathrm{mM}$. $[\mathrm{DACHPt}] /[\mathrm{Glu}]=1.0)$ to obtain MeO-DACHPt $/ \mathrm{m}$ after $120 \mathrm{~h}$ reaction at $37{ }^{\circ} \mathrm{C}$. The solution was dialyzed (Spectra/Pro 6 Membrane: MWCO, 3500) for 1 day against distilled water, and purified by ultrafiltration [molecular weight cut off (MWCO): 30,000]. The amount of DACHPt loaded into MeO-DACHPt $/ \mathrm{m}$ were measured by inductively-coupled plasma mass spectrometry (ICP-MS; 4500 ICP-MS; Hewlett Packard). For preparing Alexa 555-labeled MeO-DACHPt/m, MeO-PEG-b-P(Glu)-Alexa 555 was used instead of MeO-PEG-b-P(Glu), and the micelles were prepared by following the abovementioned method.

\section{Preparation of cRGD-installed DACHPt-loaded Micelles (cRGD-DACHPt/m)}

cRGD-DACHPt/m were prepared as previously described [44]. MeO-PEG-b-P(Glu) and Mal-PEG-b-P(Glu) copolymers (3:1 molar ratio) were mixed with DACHPt nitrate chloride solution $([\mathrm{Glu}]=5 \mathrm{mM}$. $[\mathrm{DACHPt}] /[\mathrm{Glu}]=1.0,[\mathrm{MeO}-\mathrm{PEG}-b-\mathrm{P}(\mathrm{Glu})] /[\mathrm{Mal}-\mathrm{PEG}-b-\mathrm{P}(\mathrm{Glu})]=1.0)$ to obtain maleimide-DACHPt/m (Mal-DACHPt/m) after $120 \mathrm{~h}$ reaction at $37{ }^{\circ} \mathrm{C}$. The solution was dialyzed (Spectra/Pro 6 Membrane; MWCO: 3500) for 1 day against distilled water, and purified by ultrafiltration (MWCO: 30,000). Cyclo[RGDfK(CX-)] (0.640 mM) was added to Mal-DACHPt/m 
solution to react for $18 \mathrm{~h}$ at room temperature. The solution was purified by ultrafiltration (MWCO: $100,000)$ to obtain cRGD-DACHPt $/ \mathrm{m}$. The $\mathrm{cRGD} / \mathrm{MeO}$ ratio on the surface of $\mathrm{cRGD}-\mathrm{DACHPt} / \mathrm{m}$ were confirmed by preparing the polymer mixture from cRGD-DACHPt/m solution with QuadraSil ${ }^{\mathrm{TM}}$ MP (WAKO Pure Chemical Industries Ltd.) and brine, and measuring it by ${ }^{1} \mathrm{H}-\mathrm{NMR}$ $(400 \mathrm{MHz})$ in $\mathrm{D}_{2} \mathrm{O}$ at room temperature. The amount of cRGD on the surface of micelles was fixed at $20 \%$ (a molar basis) of the total PEG chains based on our previous observations showing that the $20 \%$ cRGD-DACHPt $/ \mathrm{m}$ were most effective for suppressing the growth of cancer cells (human glioblastoma U87-MG cells) overexpressing $\alpha_{\mathrm{v}} \beta_{3} / \alpha_{\mathrm{v}} \beta_{5}$ integrins in vitro among a series of cRGD-DACHPt/m having different percentages of $\mathrm{cRGD}$ on their surface, as well as due to their prolonged circulation in blood, which was close to that of MeO-DACHPt/m [44] [45]. Moreover, the concentration of DACHPt incorporated inside the micelles was determined by ICP-MS. These cRGD-installed micelles showed comparable drug release rate to MeO-DACHPt/m [35]. To prepare Alexa 647-labeled cRGD-DACHPt/m, Mal-PEG- $b$-P(Glu)-Alexa 647 was used and the micelles were prepared as described above.

Preparation of Lymph Node Metastasis (LNM) Mouse Model

C57BL6/J mice were injected in the footpad with $10 \mu \mathrm{L}$ of a B16F10-luc murine melanoma cells suspension $\left(1 \times 10^{8}\right.$ cells $\left./ \mathrm{mL}\right)$ in RPMI 1640 medium. Tumors metastasized to their ipsilateral brachial lymph nodes within 1-week after the inoculation. The presence of lymph node metastases was confirmed by the observation with in vivo imaging system (IVIS) 10 min after intraperitoneal injection of luciferin $(150 \mathrm{mg} / \mathrm{kg})$ with 1-min exposure for photon collection. The fur of mice around their metastatic lymph node area was shaved to obtain clear bioluminescent signal. The observation was performed every 2 days after the inoculation of tumor cells to 
determine the onset of the metastatic disease. Twenty four-hours after the metastasis in lymph node was detected, the administration of drugs was initiated. This procedure allowed us to minimize the variability of the bioluminescent signal from the metastasis. Moreover, the studies were performed in 2 models, the model "with-primary-tumor", i.e. both primary tumor and metastasis were present during the evaluation of the drugs, and the model "without-primary-tumor", that is, the mice had their primary tumor on their footpad resected after the detection of their lymph node metastases. The evaluation of the drugs in the latter group was done $24 \mathrm{~h}$ after the surgery.

\section{In Vivo Antitumor Activity}

Mice $(n=5)$ with- and without-primary-tumor models were injected 3-times with PBS, MeO-DACHPt $/ \mathrm{m}$ (2 mg/kg on a DACHPt basis) and cRGD-DACHPt $/ \mathrm{m}(2 \mathrm{mg} / \mathrm{kg}$ on a DACHPt basis) on days 0,2 and 4 . The initial size of the primary tumor (day 0 ) was approximately $10 \mathrm{~mm}^{3}$ in mice of the model "with-primary-tumor". The size of the primary tumor (only in mice of the model "with-primary-tumor") was measured every 2 days with a caliper and the volume was estimated by the following equation:

$$
V=a \times b^{2} / 2
$$

where $\mathrm{a}$ and $\mathrm{b}$ represent the long and short axis of the tumor, respectively. The photon radiance from the lymph node metastases (of both tumor models) was measured every 2 days by IVIS 10 min after intraperitoneal injection of luciferin $(150 \mathrm{mg} / \mathrm{kg})$. The bioluminescent signal in the lymph nodes was quantified and taken as a parameter of the tumor burden. In addition, the body weight of mice was followed during the experiment to determine the toxicity of the drugs.

\section{Metastasis Inhibition}

Four-days after inoculation with B16F10-luc cells, mice of the model 
“with-primary-tumor" were injected intraperitoneally with luciferin $(150 \mathrm{mg} / \mathrm{kg})$ and imaged for 5 min by IVIS to confirm they still have not developed metastasis. Then, the mice were divided in 3 groups and the experiment was started, with the mice receiving 3 intravenous injections of PBS, MeO-DACHPt/m (2 mg/kg on a DACHPt basis), cRGD-DACHPt/m (2 mg/kg on a DACHPt basis) and MeO-DACHPt $/ \mathrm{m}(2 \mathrm{mg} / \mathrm{kg}$ on a DACHPt basis) mixed with free cRGD peptide $(37 \mu \mathrm{g} / \mathrm{kg}$, which is similar to the amount conjugated on cRGD-DACHPt $/ \mathrm{m}$ ) on days 0,2 and 4 . Then, bioluminescent imaging with 5 min exposure was repeated every 2 days to examine the incidence of LNM. The statistical significance was determined by Fisher's exact test.

\section{Drug Accumulation in Metastatic Lymph Nodes}

Drug accumulation was evaluated by using the models "with-primary-tumor" and “without-primary-tumor" ( $\mathrm{n}=8$ for micelles and $\mathrm{n}=4$ for oxaliplatin). MeO-DACHPt $/ \mathrm{m}(5 \mathrm{mg} / \mathrm{kg}$ on a DACHPt basis), cRGD-DACHPt/m (5 mg/kg on a DACHPt basis), or the free platinum drug, oxaliplatin $(5 \mathrm{mg} / \mathrm{kg})$ were injected intravenously, and the metastatic lymph nodes were harvested 24 $\mathrm{h}$ after the injection. Then, the tissues were digested in hot $90 \%$ nitric acid, and the solutions were evaporated to dryness. The Pt amount in the metastatic lymph nodes was then measured by ICP-MS, after reconstituting the solution with $1 \%$ nitric acid. The significance of the results was determined by Student's t-test.

\section{Intravital confocal laser scanning microscopy of metastatic lymph nodes}

The intravital confocal laser scanning microscopy was done as previously reported [27]. The B16F10-GFP metastatic brachial lymph node was surgically exposed $48 \mathrm{~h}$ after resection of primary tumor, and then the lymph node was fixed by using a vacuum system [46]. Alexa 555-labeled MeO-DACHPt/m and Alexa 647-labeled cRGD-DACHPt $/ \mathrm{m}$ at a dose of $10 \mathrm{mg} / \mathrm{kg}$ on a 
DACHPt basis were co-injected into the tail vein. A Nikon A1R confocal laser scanning microscope system with ECLIPSE FN1 (Nikon, Japan) was used to acquire all in vivo pictures. Alexa 555-labeled MeO-DACHPt/m and Alexa 647-labeled cRGD-DACHPt/m were detected by using 560/620 nm excitation/emission filters and 633/670 excitation/emission filters, respectively.

\section{Isolation of Tumor Cells from Lymph Node Metastases}

The metastatic lymph nodes were harvested 10 days after the tumor cell inoculation. The tissues were minced with a cell strainer processed in $1 \mathrm{x}$ trypsin-EDTA solution for $30 \mathrm{~min}$ in $37^{\circ} \mathrm{C}$, and filtered. The cell suspension was then added in the RPMI 1640 with $10 \%$ FBS, and incubated in $37{ }^{\circ} \mathrm{C}$ until the cells reached confluent. This process was repeated 2 more times to prepare B16F10-luc-LN3 cells.

In vitro Cytotoxicity Assay

B16F10-luc, B16F10-luc-LN3 cells cultured in 96-well multiplates with RPMI 1640 medium containing 10\% FBS, while HUVEC were plated on collagen I-coated 96-well multiplates and supplemented with EBM ${ }^{\mathrm{TM}}-2$ BulletKit ${ }^{\mathrm{TM}}$ medium $\left(100 \mu \mathrm{L}, 5 \times 10^{3}\right.$ cells). Twenty-four hours later, serially diluted MeO-DACHPt/m or cRGD-DACHPt/m were added into the wells (100 $\mu \mathrm{L} /$ well), and $6 \mathrm{~h}$ later the media containing the micelle solutions were removed. Then, fresh medium was added and the cells were cultured for another $48 \mathrm{~h}$. Finally, the cell viability was evaluated by using Cell Counting Kit-8 (Dojindo, Tokyo, Japan). A similar experiment was performed on B16F10-luc or B16F10-luc-LN3 cells cultured on 96-well Cell-able Oncology ${ }^{\mathrm{TM}}$ plates $\left(100 \mu \mathrm{L}, 1 \times 10^{3}\right.$ cells) for $48 \mathrm{~h}$ to assemble multicellular spheroids. The spheroids were exposed to serially diluted MeO-DACHPt/m or cRGD-DACHPt $/ \mathrm{m}$ for $6 \mathrm{~h}$, and then washed with fresh media. The cell viability of the spheroids was determined by bioluminescent imaging by IVIS 
after addition of $100 \mu \mathrm{L}$ of luciferin $(15 \mathrm{mg} / \mathrm{mL})$.

In Vitro Wound Healing Assay

The B16F10-luc-LN3 tumor cells in medium containing 10\% FBS (400 $\mu \mathrm{L}, 8 \times 10^{4}$ cells) were seeded in 24-well multiplates. When the cells reached confluence, a 1-mm width scratch was created in the cell monolayer of each well by using a $200 \mu \mathrm{L}$ pipette tip $(n=4)$. The medium and floating cells were removed, the attached cells were washed with PBS, and pictures of the scratch were taken. Then, we added new medium containing $10 \%$ FBS and drugs, namely, cRGD-DACHPt/m (6 $\mu \mathrm{M}$ of a DACHPt basis), MeO-DACHPt/m (6 $\mu \mathrm{M}$ of a DACHPt basis), MeO-DACHPt $/ \mathrm{m}(6 \mu \mathrm{M}$ of a DACHPt basis) with free cRGD peptide $(0.05 \mu \mathrm{g} / \mathrm{mL}$, which is similar to that conjugated on the micelles), free cRGD peptide $(0.05 \mu \mathrm{g} / \mathrm{mL})$, and PBS. Then, the pictures of the scratches were taken again after $10 \mathrm{~h}$ of incubation. The distance of cell migration was measured by comparing these initial pictures and $10 \mathrm{~h}$ pictures by using ImageJ. In addition, the effect of the concentration of free cRGD peptide of the cell migration was studied using the same method. The statistical significance was determined by using Student's t-test.

\section{In Vitro Cytoselect ${ }^{\mathrm{TM}}$ Cell Migration Assay}

This experiment was performed by using Cytoselect ${ }^{\mathrm{TM}}$ 96-well cell migration assay (8 $\mu \mathrm{m})$ (Cell Biolabs; San Diego, CA). RPMI-1640 medium containing 10\% FBS was added into the wells of the feeder tray, followed by placing the membrane chamber into the feeder tray. B16F10-luc-LN3 tumor cells (5 x 10³ cells) in RPMI-1640 medium with drug solution were added into the wells $(n=6)$ of the membrane chamber, and the plate was incubated for $24 \mathrm{~h}$. cRGD-DACHPt/m solution (24 $\mu \mathrm{M}$ of a DACHPt basis), MeO-DACHPt/m (24 $\mu \mathrm{M}$ of a DACHPt basis) were added to the wells. The cells migrating through the membrane after $20 \mathrm{~h}$ incubation 
were detached by Cell Detachment Solution provided in the kit and the cell number was evaluated by IVIS after adding $100 \mu \mathrm{L}$ luciferin $(15 \mathrm{mg} / \mathrm{mL})$. The statistical significance was determined by using Student's t-test.

\section{Results and Discussion}

In Vivo Antitumor Activity and Metastasis Inhibition

$\mathrm{MeO}-\mathrm{DACHPt} / \mathrm{m}$ and Mal-DACHPt/m were prepared by mixing DACHPt with MeO-PEG- $b$-P(Glu) and MeO-PEG- $b$-P(Glu)/Mal-PEG-b-P(Glu) (mixture in 3:1 molar ratio), respectively. To prepare cRGD-DACHPt/m, we then conjugated cRGD peptide on $20 \%$ of the PEG chains of Mal-DACHPt/m, as this degree of conjugation can provide $\mathrm{cRGD}$-installed micelles with sufficient targeting ability for $\alpha_{\mathrm{v}} \beta_{3} / \alpha_{\mathrm{v}} \beta_{5}$ integrins [44] and still achieve an extended blood circulation comparable to that of MeO-DACHPt/m $[44,45]$. The size distribution, the drug loading and the zeta-potential of the micelles were determined and presented in Table 1. Both MeO-DACHPt/m and cRGD-DACHPt/m showed comparable size, drug incorporation and surface charge, which allow us to attribute their differences in activity to the ligand installation.

Table 1. Size, drug loading and zeta-potential of MeO-DACHPt $/ \mathrm{m}$ and cRGD-DACHPt $/ \mathrm{m}$.

\begin{tabular}{ccccc}
\hline Micelle & Diameter $(\mathrm{nm})^{\mathrm{a}}$ & PDI & {$[\mathrm{Pt}] /[\mathrm{COO}](\mathrm{mol} / \mathrm{mol})^{\mathrm{b}}$} & ${\text { Zeta potential }(\mathrm{mV})^{\mathrm{c}}}^{\mathrm{c}}$ \\
\hline $\mathrm{MeO}-\mathrm{DACHPt} / \mathrm{m}$ & 27 & 0.1 & 0.51 & $-3.1 \pm 0.5$ \\
$\mathrm{cRGD}-\mathrm{DACHPt} / \mathrm{m}$ & 29 & 0.1 & 0.52 & $-2.3 \pm 0.4$ \\
\hline
\end{tabular}

${ }^{a}$ Determined by dynamic light scattering

${ }^{\mathrm{b}}$ Determined by ICP-MS

${ }^{\mathrm{c}}$ Determined by laser doppler micro-electrophoresis 
The in vivo antitumor activity of the micelles, as well as their ability to inhibit the metastasis formation was studied in C57BL6/J mice $(n=10)$ bearing B16F10-luc cells orthotopically inoculated in their footpad. It is worth noting that the burden of these melanoma cells can be quantified by bioluminescence imaging with IVIS after intraperitoneal injection of luciferin, and the incidence and growth of metastasis can be evaluated by this way. By using this model, we have recently demonstrated that $\mathrm{MeO}-\mathrm{DACHPt} / \mathrm{m}$ can selectively target both the primary tumors and LNM after systemic administration, with significantly higher efficacy than oxaliplatin [37]. Herein, 4-days after inoculation, when the primary tumors were approximately $10 \mathrm{~mm}^{3}$, and the bioluminescence imaging confirmed that the mice were yet to have LNM, we challenged the micelles against primary tumors and the development of metastasis. Accordingly, PBS (control), MeO-DACHPt $/ \mathrm{m}$ (2 mg/kg on a DACHPt basis), cRGD-DACHPt $/ \mathrm{m}$ ( $2 \mathrm{mg} / \mathrm{kg}$ on a DACHPt basis), and MeO-DACHPt/m (2 mg/kg on a DACHPt basis) mixed with free cRGD peptide (37 $\mu \mathrm{g} / \mathrm{kg}$, which is similar to the conjugated amount on cRGD-DACHPt $/ \mathrm{m}$ ) were injected intravenously for 3 times every $2^{\text {nd }}$ day, i.e. days 0,2 and 4 . The effect of the drugs on the volume of primary tumors was followed every other day by using a caliper. Both MeO-DACHPt/m and cRGD-DACHPt/m showed similar suppression of the tumor growth (Figure 2A), indicating that cRGD installation on the micelles did not improve the efficacy against the primary tumors in the footpads. Moreover, the occurrence of lymph node metastases was followed by bioluminescence imaging every other day with IVIS set at 5-min exposure. Ten days after the start of the treatment, cRGD-DACHPt/m displayed significant inhibition of the LNM formation even compared with MeO-DACHPt/m $(\mathrm{p}<$ 0.05; Table 2), and the combination of free cRGD peptide and MeO-DACHPt/m did not improve the inhibition of metastasis, as the degree of metastasis formation is higher than that of cRGD-DACHPt/m (Table 2). During the treatment, the body weight of the mice was also monitored as a parameter of toxicity. Accordingly, mice receiving micelles did not show any loss in 
their body weight, which was comparable to that of mice receiving PBS (Figure 2B), indicating the safety of the therapies.
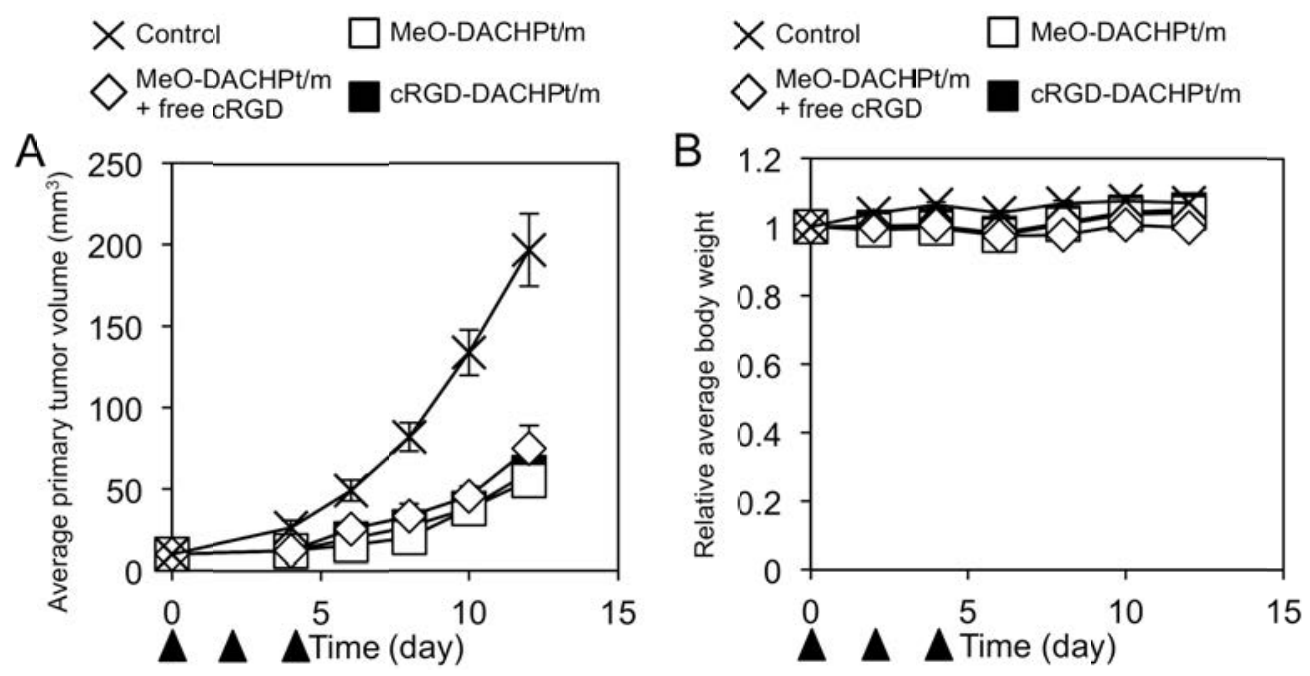

Figure 2. In vivo antitumor activity against primary melanoma tumors. A. PBS (control; crosses), MeO-DACHPt $/ \mathrm{m}$ at $2 \mathrm{mg} / \mathrm{kg}$ (white squares), cRGD-DACHPt $/ \mathrm{m}$ at $2 \mathrm{mg} / \mathrm{kg}$ (black squares) and $\mathrm{MeO}-\mathrm{DACHPt} / \mathrm{m}$ at $2 \mathrm{mg} / \mathrm{kg}$ plus free cRGD peptide at $37 \mu \mathrm{g} / \mathrm{kg}$ (white diamonds) were intravenously injected on days 0,2 and 4 (black triangles: injection points). Data presented as the mean \pm S.E. $(n=10)$. B. Relative body weight during the treatment. Data presented as the mean \pm S.E. $(\mathrm{n}=10)$.

Table 2. Incidence of lymph node metastasis (LNM) during the antitumor activity of MeO-DACHPt/m, MeO-DACHPt/m plus free cRGD peptide, and cRGD-DACHPt/m against orthotopic melanoma tumors.

\begin{tabular}{|c|c|c|c|c|}
\hline Treatment & Saline $^{a}$ & $\mathrm{MeO}-\mathrm{DACHPt} / \mathrm{m}^{\mathrm{b}}$ & $\mathrm{MeO}-\mathrm{DACHPt} / \mathrm{m}+\mathrm{cRGD}$ & cRGD-DACHPt $/ \mathrm{m}^{\mathrm{d}}$ \\
\hline day & & & peptide $^{c}$ & \\
\hline 4 & $3 / 9$ & $0 / 11$ & $1 / 6$ & $0 / 10$ \\
\hline 10 & $9 / 9$ & $9 / 11$ & $5 / 6$ & $3 / 10$ \\
\hline
\end{tabular}


${ }^{\mathrm{a}}$ Saline solution was injected every second day on days 0,2 and $4(\mathrm{n}=9)$.

${ }^{\mathrm{b}} \mathrm{MeO}-\mathrm{DACHPt} / \mathrm{m}$ were injected at $2 \mathrm{mg} / \mathrm{kg}$ every second day on days 0,2 and $4(\mathrm{n}=11)$.

${ }^{\mathrm{c}} \mathrm{MeO}-\mathrm{DACHPt} / \mathrm{m}$ at $2 \mathrm{mg} / \mathrm{kg}$ plus free cRGD peptide at $37 \mu \mathrm{g} / \mathrm{kg}$ were injected every second day on days 0,2 and $4(n=6)$.

${ }^{d}$ cRGD-DACHPt $/ \mathrm{m}$ at $2 \mathrm{mg} / \mathrm{kg}$ were injected every second day on days 0,2 and $4(\mathrm{n}=10)$.

The micelles were then evaluated against the tumor model having developed LNM. The model was prepared by injecting B16F10-luc cells in the footpad of C57BL6/J mice, and the treatment was started $24 \mathrm{~h}$ after confirming the presence of lymph node metastases by 1-min exposure in IVIS. Previously, we reported that the size of B16F10-luc metastasis in the lymph nodes at this point, and with these IVIS settings, is approximately $200 \mu \mathrm{m}$ [37]. MeO-DACHPt/m and cRGD-DACHPt/m were then intravenously injected at $2 \mathrm{mg} / \mathrm{kg}$ on a DACHPt basis, and the administration of micelles was repeated every $2^{\text {nd }}$ day for 3 times. Results demonstrated that both MeO-DACHPt $/ \mathrm{m}$ and cRGD-DACHPt $/ \mathrm{m}$ have comparable suppression of the growth of the primary tumors in the footpads (Supplementary Figure S1), which matches our results in the orthotopic tumors pre-formation of metastasis (Figure 2A). However, mice treated with cRGD-DACHPt/m had significantly smaller LNM than mice treated with MeO-DACHPt/m, showing a prolonged suppression of the metastatic growth (Figure 3). Together, these results suggest that the superior inhibition of LNM formation and antitumor effect against LNM of cRGD-DACHPt/m is not caused by disparities in their activity against primary tumors, as both $\mathrm{MeO}-\mathrm{DACHPt} / \mathrm{m}$ and cRGD-DACHPt $/ \mathrm{m}$ showed no difference in the suppression of tumor progression, neither by toxicity issues of these formulations. Therefore, we postulated three possible mechanisms for the improved inhibition and efficacy against LNM of cRGD-DACHPt/m, as follows: 1. cRGD-DACHPt/m may be more cytotoxic than MeO-DACHPt/m against B16F10-luc 
cells forming metastasis, since several reports have indicated that metastatic cancer cells have higher levels of $\alpha_{v} \beta_{3} / \alpha_{v} \beta_{5}$ integrins [47], including melanoma [48,49]; 2. cRGD-DACHPt/m may have stronger activity than $\mathrm{MeO}-\mathrm{DACHPt} / \mathrm{m}$ against metastastic foci in the lymph nodes, either by being more cytotoxic or effectively increasing drug levels; 3. cRGD-DACHPt/m may inhibit the migration of cancer cells to lymph nodes more effectively than MeO-DACHPt/m, as the expression of $\alpha_{v} \beta_{3}$ integrin on tumor cells has been linked to enhanced transendothelial migration [50,51], particularly in melanoma [52], and cRGD peptides are potent inhibitors of this spreading process $[52]$.

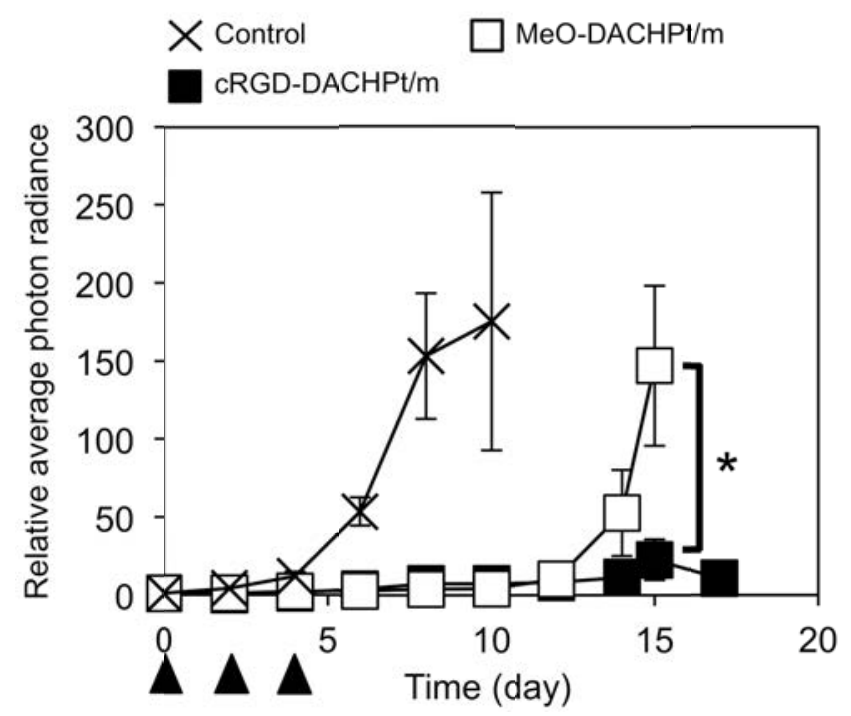

Figure 3. In vivo antitumor activity against developed tumor metastasis in mice having their primary tumor ("with-primary-tumor" model). PBS (control), MeO-DACHPt/m at $2 \mathrm{mg} / \mathrm{kg}$ (white squares) and cRGD-DACHPt $/ \mathrm{m}$ at $2 \mathrm{mg} / \mathrm{kg}$ (black squares) were intravenously injected on days 0, 2 and 4 (black triangles: injection points). Data presented as the mean \pm S.E. $(n=5)$.

In Vitro Cytotoxicity

To study our first proposed mechanism for the improved metastasis inhibition of cRGD-DACHPt $/ \mathrm{m}$, the cytotoxicity of the micelles was evaluated in B16F10-luc cells, as well as in tumor cells collected from the LNM (B16F10-luc-LN3). The cytotoxicity assay was first performed 
against monolayer-cultured B16F10-luc and B16F10-luc-LN3 cells. The cells were plated for $24 \mathrm{~h}$, and exposed to MeO-DACHPt/m and cRGD-DACHPt $/ \mathrm{m}$ for $6 \mathrm{~h}$. Then, the micelles' solutions were removed, and the cells were washed and post-incubated for $48 \mathrm{~h}$ to finally determine the cell viability by using Cell Counting Kit- 8 . Accordingly, the $50 \%$ inhibitory concentrations $\left(\mathrm{IC}_{50}\right)$ of MeO-DACHPt $/ \mathrm{m}$ and cRGD-DACHPt/m were found to be comparable against both B16F10-luc and B16F10-luc-LN3 cells (Table 3), denoting the similar activity of the micelles against the original B16F10-luc cells and the melanoma cells in the LNM. In addition, we evaluated the cytotoxicity of the micelles against B16F10-luc and B16F10-luc-LN3 cells in spheroid culture, which is more relevant to the in vivo situation than monolayer culture [53]. The cancer cell spheroids were cultured for $48 \mathrm{~h}$ in 96 -well plates with each well containing a patterned array of $100-\mu \mathrm{m}$ nanowells, which are surrounded by PEG to prevent cell adherence. Then, the spheroids were exposed to MeO-DACHPt/m and cRGD-DACHPt/m for $6 \mathrm{~h}$, washed and post-incubated $48 \mathrm{~h}$ with fresh medium. The cell viability of the B16F10-luc and B16F10-luc-LN3 spheroids was determined by adding luciferin to each well and quantifying the bioluminescent signal by IVIS. The $\mathrm{IC}_{50}$ values of $\mathrm{MeO}-\mathrm{DACHPt} / \mathrm{m}$ and $\mathrm{cRGD}-\mathrm{DACHPt} / \mathrm{m}$ in spheroids of $\mathrm{B} 16 \mathrm{~F} 10-\mathrm{luc}$ or B16F10-luc-LN3 cells were comparable (Table 3). The cytotoxicity of both micelles against HUVEC was comparable and lower than that of micelles against B16F10-luc and B16F10-luc-LN3, suggesting that the in vivo activity of these micelles is mainly toward cancer cells rather than vascular endothelial cells of tumors (Table 3). Thus, the analogous cytotoxicity of $\mathrm{MeO}-\mathrm{DACHPt} / \mathrm{m}$ and cRGD-DACHPt $/ \mathrm{m}$ observed for the more metastatic sub-line, B16F10-luc-LN3, cannot explain the improved inhibition of metastasis formation and efficacy against LNM of cRGD-DACHPt/m, thereby, we proceeded to test our second and third hypotheses.

Table 3. In vitro cytotoxicity of $\mathrm{MeO}-\mathrm{DACHPt} / \mathrm{m}$ and $\mathrm{cRGD}-\mathrm{DACHPt} / \mathrm{m}$ against 
HUVEC, and B16F10-luc and lymph node metastatic B16F10-luc-LN3 cells.

\begin{tabular}{|c|c|c|c|c|c|}
\hline \multirow{3}{*}{ Micelles } & \multicolumn{5}{|c|}{$\mathrm{IC}_{50}(\mu \mathrm{M})$} \\
\hline & \multicolumn{3}{|c|}{ Monolayer culture $^{\mathrm{a}}$} & \multicolumn{2}{|c|}{ Spheroid culture $^{\mathrm{b}}$} \\
\hline & HUVEC & B16F10-luc & B16F10-luc-LN3 & B16F10-luc & B16F10-luc-LN3 \\
\hline $\mathrm{MeO}-\mathrm{DACHPt} / \mathrm{m}$ & $460 \pm 20$ & $10 \pm 1.3$ & $2.5 \pm 0.08$ & $3.8 \pm 0.09$ & $0.91 \pm 0.03$ \\
\hline cRGD-DACHPt/m & $470 \pm 20$ & $10 \pm 1.6$ & $5.0 \pm 0.16$ & $4.3 \pm 0.20$ & $1.1 \pm 0.05$ \\
\hline
\end{tabular}

${ }^{a}$ Determined by Cell Counting Kit. Data presented as the mean \pm S.E. $(n=6)$.

${ }^{b}$ Determined by bioluminescence imaging. Data presented as the mean \pm S.E. $(n=6)$.

\section{In Vivo Antitumor Activity against LNM after Tumor Resection}

To study the second proposed mechanism for the enhanced metastasis inhibition of cRGD-DACHPt/m, the in vivo antitumor activity of the micelles was evaluated against developed metastasis in the lymph nodes after resection of the primary tumor, which allows us to discriminate the antitumor effect of the micelles against the metastastic foci. To prepare the animal model, B16F10-luc cells were injected in the footpad of C57BL6/J mice, the tumors were allowed to grow, and the presence of the lymph node metastases was confirmed after 1-min exposure in IVIS. Then, the primary tumors were resected, and the evaluation of the antitumor activity of intravenously injected MeO-DACHPt/m (2 mg/kg on a DACHPt basis) or cRGD-DACHPt/m $(2 \mathrm{mg} / \mathrm{kg}$ on a DACHPt basis) was initiated $24 \mathrm{~h}$ later. Contrary to the results obtained in the model "with-primary-tumor" (Figure 3), MeO-DACHPt/m and cRGD-DACHPt/m showed no difference in the antitumor activity against the LNM when the primary tumor was removed (Figure 4). 


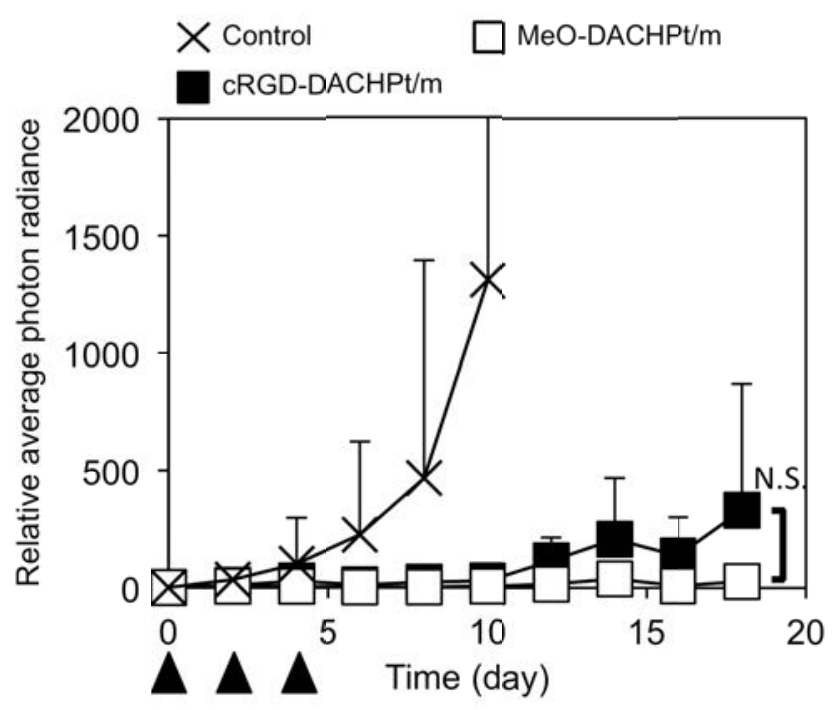

Figure 4. In vivo antitumor activity against developed tumor metastasis in mice having their primary tumor resected (“without-primary-tumor" model). PBS (control), MeO-DACHPt/m at $2 \mathrm{mg} / \mathrm{kg}$ (white squares) and cRGD-DACHPt/m at $2 \mathrm{mg} / \mathrm{kg}$ (black squares) were intravenously injected on days 0, 2 and 4 (black triangles: injection points). Data presented as the mean \pm S.E. (n $=5)$.

The ability of MeO-DACHPt $/ \mathrm{m}$ and cRGD-DACHPt $/ \mathrm{m}$ for accumulating in the metastatic lymph nodes was also evaluated in the models "with-primary-tumor" and "without-primary-tumor" $24 \mathrm{~h}$ after intravenous injection. The amount of Pt delivered by the micelles was quantified by ICP-MS after dissolving the metastatic lymph nodes with nitric acid. Results showed that both MeO-DACHPt/m and cRGD-DACHPt/m have high accumulation in the metastatic lymph nodes (Figure 5A and B), which was higher than that of the free platinum drug (oxaliplatin) indicating the enhanced delivery of the micelles to the metastasis. The level of accumulation was similar to our previously reported values for MeO-DACHPt/m in LNM [37]. However, the difference in the Pt levels of MeO-DACHPt $/ \mathrm{m}$ and cRGD-DACHPt $/ \mathrm{m}$ in the metastatic lymph nodes was not significant, irrespective of the presence of primary tumor (Figure 5A and B). This high accumulation tendency was also observed $48 \mathrm{~h}$ after intravenous injection, 
suggesting that both micelles can be effectively retained in the metastatic lymph nodes (Supplementary Figure S2). Moreover, the accumulation of cRGD-DACHPt $/ \mathrm{m}, \mathrm{MeO}-\mathrm{DACHPt} / \mathrm{m}$, and oxaliplatin was also evaluated in healthy lymph nodes 24 and $48 \mathrm{~h}$ after intravenous injection to confirm the targeting ability of micelles to metastatic nodes. The levels of MeO-DACHPt $/ \mathrm{m}$ in healthy lymph nodes were always lower than in metastatic lymph nodes, indicating their selective accumulation in the metastases (Supplementary Figure S3). For cRGD-DACHPt/m, the accumulation in both healthy and metastatic nodes was comparable at $24 \mathrm{~h}$, probably because of the presence of integrins, such as $\alpha 5 \beta 1$ integrin, in the endothelial cells of the venules of lymph nodes [54], which could promote the binding of cRGD peptides [55]. Nevertheless, $48 \mathrm{~h}$ after injection, the level of cRGD-DACHPt/m in healthy lymph nodes decreased to an amount comparable to that of MeO-DACHPt/m, indicating negligible retention in healthy nodes and selectivity to the nodal metastases (Supplementary Figure S3). In addition, by using intravital laser scanning confocal microscopy, we assessed the real-time extravasation and penetration of fluorescent-labeled Alexa555-MeO-DACHPt/m and Alexa647-cRGD-DACHPt/m within lymph node metastases. The results demonstrated both micelles effectively penetrated in the metastatic foci, showing comparable penetration profiles from the vasculature (Supplementary Figure S4). Thus the similar degree of accumulation of MeO- and cRGD-DACHPt/m in the models "with-primary-tumor" and "without-primary-tumor", the comparable activity of both micelles against orthotopic tumors and metastasis alone, and their ability to reach the metastatic foci, together with the aforementioned analogous cytotoxicity of the micelles against B16F10-luc-LN3 cells and reduced toxicity to HUVEC (Table 2), fail to clarify the superior inhibitory activity and efficacy of cRGD-DACHPt/m against LNM in the presence of the primary tumor (Table 2 and Figure 3). .Therefore, the capacity of cRGD-DACHPt/m for suppressing the migration of melanoma cells was further studied to determine the relation with the ability of these micelles for obstructing metastasis development and 
enhancing the antitumor activity.
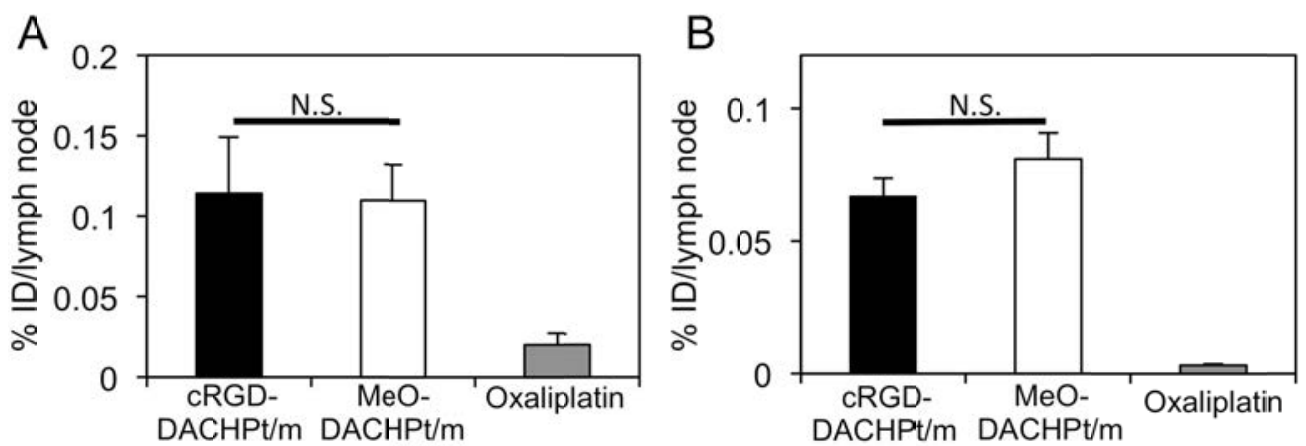

Figure 5. Pt drug levels in metastatic lymph nodes $24 \mathrm{~h}$ after the intravenous injection of MeO-DACHPt $/ \mathbf{m}$ or cRGD-DACHPt $/ \mathbf{m}$. A. Accumulation of Pt drug in the metastatic lymph nodes of the "with-primary-tumor" model. Data presented as the mean \pm S.E. $(n=4)$. B. Accumulation of Pt drug in the metastatic lymph nodes of the "without-primary-tumor". Data presented as the mean \pm S.E. ( $n=8$ for micelles and $n=4$ for oxaliplatin).

\section{In Vitro Inhibition of Cell Migration}

Our third proposed mechanism for the superior inhibition and activity of cRGD-DACHPt $/ \mathrm{m}$, that is, the effective inhibition of the migration of cancer cells to lymph nodes, was first tested by an in vitro wound-healing assay with monolayer-cultured B16F10-luc cells, as this assay has been widely used in the study of cancer cell migration [56]. After the B16F10-luc cells were grown to $80 \%$ confluence in 6 well-plates, a 1-mm width scratch was made, followed by the addition of the drugs diluted in cell culture media. Ten-hours later, we measured the average distance that the cells migrated in the horizontal direction. The results showed that both MeO-DACHPt $/ \mathrm{m}$ and cRGD-DACHPt/m reduced the cell migration compared to PBS treated cells, though cRGD-DACHPt/m were significantly more effective than MeO-DACHPt/m (Figure 6A). Moreover, the inhibitory effect of MeO-DACHPt/m plus free $c$ RGD peptide was lower than that of cRGD-DACHPt $/ \mathrm{m}$, indicating that the conjugation of cRGD peptide on the surface of micelles is 
necessary for the improved inhibition of cell migration, which is consistent with our in vivo observations (Table 2). The migration of B16F10-luc cells after treatment with the micelles was also evaluated by using a Transwell migration assay. It was confirmed that the inhibition effect of cRGD-DACHPt/m on cell migration was higher than that of MeO-DACHPt/m also by this assay (Figure 6B). These results indicate that $\mathrm{cRGD}-\mathrm{DACHPt} / \mathrm{m}$ can effectively reduce cell migration compared with $\mathrm{MeO}-\mathrm{DACHPt} / \mathrm{m}$, and could explain the superior in vivo inhibition of the formation of LNM of RGD-DACHPt/m, as well as their activity against LNM in the presence of primary tumors.
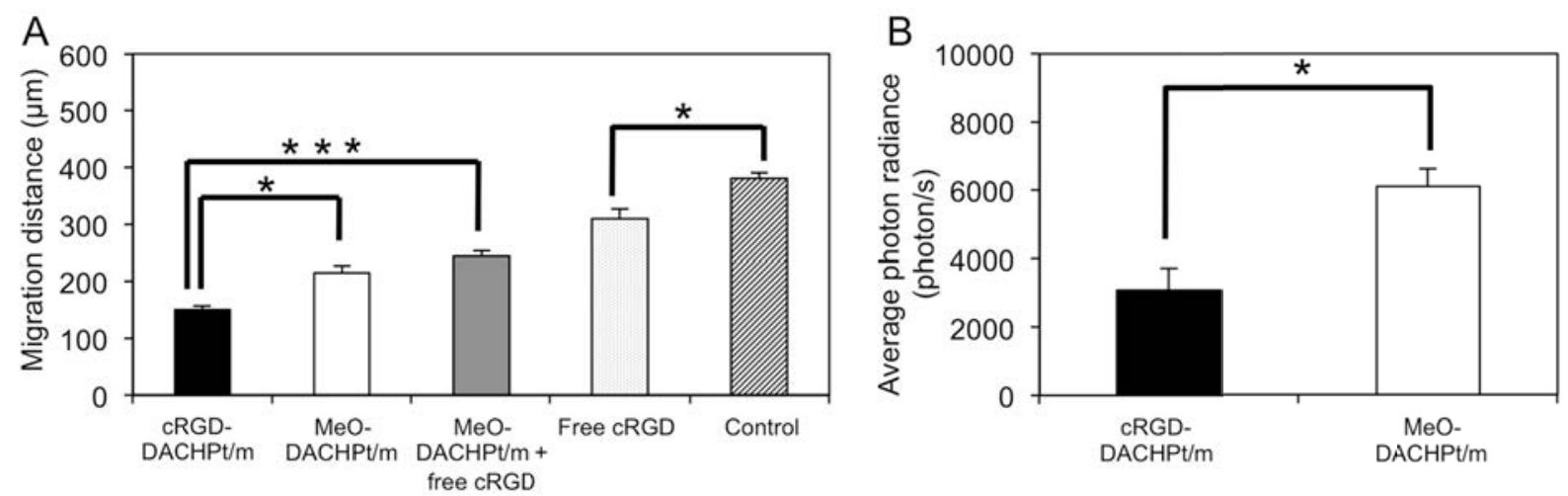

Figure 6. In vitro inhibition of B16F10 migration after incubation with PBS, micelles or free

cRGD peptide. A. Migration distance in a wound-healing assay using monolayer-cultured B16F10-luc cells. Data presented as the mean \pm S.E. $(\mathrm{n}=4) . * \mathrm{P}<0.05, * * * \mathrm{P}<0.001$ by Student's t-test. B. Migration of cells in a Transwell migration assay. The bioluminescence corresponds to the migrated cells. Data presented as the mean \pm S.E. $(n=6) . * P<0.05$ by Student's t-test.

The effect of free cRGD peptide on the migration of B16F10 cells was also studied to determine its concentration-dependent inhibitory capability on cell migration, and to compare it with that of cRGD-DACHPt $/ \mathrm{m}$. The migration of the cancer cells was inhibited at cRGD peptide concentrations higher than $1 \mu \mathrm{g} / \mathrm{mL}$, while at lower concentrations the migration of the melanoma cells was not affected (Figure 7). Compared to the free cRGD peptide, cRGD-DACHPt/m required 
much less cRGD peptide concentration $(0.05 \mu \mathrm{g} / \mathrm{mL})$ to effectively reduce the migration of the cancer cells. Though this could be attributed just to the combination of cRGD peptide and DACHPt $/ \mathrm{m}$, such mixture was less effective than cRGD-DACHPt/m to suppress migration (Figure 6A). Another explanation could be that the cRGD-DACHPt $/ \mathrm{m}$ are capable of three-dimensional and multivalent binding on the cancer cells, which could be more effective for inhibiting cell migration than the binding of single cRGD peptides. Indeed, nanoparticles having cRGD peptides on their surface displayed simultaneous binding with multiple $\alpha_{v} \beta_{3}$ integrin domains over extended areas of cell membranes, which resulted in stronger binding affinities and higher inhibition of cell adhesion than free cRGD [57]. This multivalent binding of cRGD-installed nanoparticles to the $\alpha_{v} \beta_{3}$ integrins on cells resembles that of the RGD motifs on the extracellular matrix to integrins, occurring through multipoint attachments with the strength regulated by multivalent effects [57]. In vivo, in addition to the multivalent capacity of cRGD-DACHPt $/ \mathrm{m}$, the micelles can also extend the blood circulation of the conjugated cRGD peptides and increase their levels in tumor tissues, thereby, acting with considerably greater inhibitory activity than the free peptide [58].

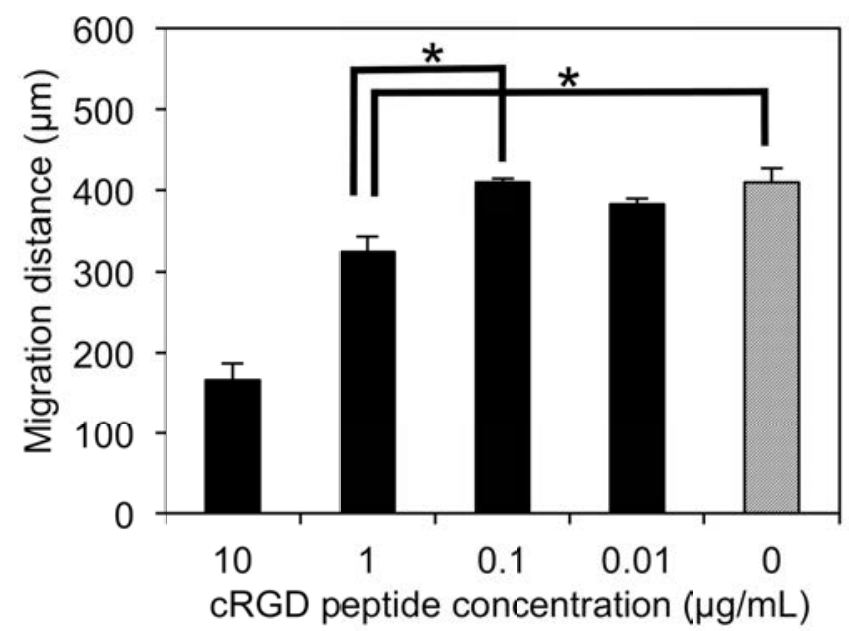

Figure 7. Migration distance in a wound-healing assay using monolayer-cultured B16F10-luc cells incubated with different concentrations of cRGD peptide. Data presented as the mean \pm S.E. $(\mathrm{n}=4) . * \mathrm{P}<0.05$ by Student's t-test. 


\section{Conclusions}

Our results indicate that cRGD-DACHPt/m significantly improved the efficacy of the treatment against LNM in the presence of the primary melanoma by effectively inhibiting the spread of cancer cells from the primary tumor to the lymph nodes combined with their potency against the established metastatic foci in lymph nodes. The installation of cRGD peptides on the surface of the micelles was essential for this enhancement of the efficacy, as the activity of the mixture of free cRGD peptide and MeO-DACHPt $/ \mathrm{m}$ were comparable to that of $\mathrm{MeO}-\mathrm{DACHPt} / \mathrm{m}$ alone, probably because cRGD-DACHPt/m increased the intratumoral levels of cRGD peptides, as well as their ability for multivalent binding to $\alpha_{\mathrm{v}} \beta_{3}$ integrins on cancer cells. The similar activities of both $\mathrm{MeO}-\mathrm{DACHPt} / \mathrm{m}$ and cRGD-DACHPt/m against primary melanoma and the established LNM supports the proposed mechanism for the activity enhancement of cRGD-DACHPt/m against LNM having primary tumor, but also suggest that the therapeutic improvements through targeting may not apply to every step of tumor progression. Understanding which steps are subtle for targeting could increase the efficiency of nanomedicine-based targeted therapies. Along these lines, our findings provide a rationale for designing targeted nanomedicines with enhanced efficacy against metastatic disease through cooperative inhibition of metastatic spread and growth of metastatic foci.

\section{References}

[1] G.P. Gupta, J. Massagué, Cancer Metastasis: Building a Framework, Cell. 127 (2006) 679695. doi:10.1016/j.cell.2006.11.001.

[2] S. Shu, A.J. Cochran, R.-R. Huang, D.L. Morton, H.T. Maecker, Immune responses in the draining lymph nodes against cancer: implications for immunotherapy., Cancer Metastasis Rev. 25 (2006) 233-242. doi:10.1007/s10555-006-8503-7. 
[3] A. Rizwan, C. Bulte, A. Kalaichelvan, M. Cheng, B. Krishnamachary, Z.M. Bhujwalla, et al., Metastatic breast cancer cells in lymph nodes increase nodal collagen density, Sci. Rep. 5 (2015) 10002. doi:10.1038/srep10002.

[4] R.M. Kwee, T.C. Kwee, Predicting lymph node status in early gastric cancer, Gastric Cancer. 11 (2008) 134-148. doi:10.1007/s10120-008-0476-5.

[5] T. Tammela, K. Alitalo, Lymphangiogenesis: Molecular Mechanisms and Future Promise, Cell. 140 (2010) 460-476. doi:10.1016/j.cell.2010.01.045.

[6] E.J.C. Nieuwenhuis, Assessment and Clinical Significance of Micrometastases in Lymph Nodes of Head and Neck Cancer Patients Detected by E48 (Ly-6D) Quantitative Reverse Transcription-Polymerase Chain Reaction, Lab. Investig. 83 (2003) 1233-1240. doi:10.1097/01.LAB.0000083532.46536.56.

[7] K. Kawada, M.M. Taketo, Significance and mechanism of lymph node metastasis in cancer progression, Cancer Res. 71 (2011) 1214-1218. doi:10.1158/0008-5472.CAN-10-3277.

[8] E.R. Pereira, D. Jones, K. Jung, T.P. Padera, The lymph node microenvironment and its role in the progression of metastatic cancer, Semin. Cell Dev. Biol. 38 (2015) 98-105. doi:10.1016/j.semcdb.2015.01.008.

[9] S. Hirakawa, L.F. Brown, S. Kodama, K. Paavonen, K. Alitalo, M. Detmar, VEGF-C induced lymphangiogenesis in sentinel lymph nodes promotes tumor metastasis to distant sites, Blood. 109 (2007) 1010-1017. doi:10.1182/blood-2006-05-021758.The.

[10] J.-K. Cho, S.H. Hyun, N. Choi, M.-J. Kim, T.P. Padera, J.Y. Choi, et al., Significance of Lymph Node Metastasis in Cancer Dissemination of Head and Neck Cancer, Transl. Oncol. 8 (2015) 119-125. doi:10.1016/j.tranon.2015.03.001.

[11] S. a Stacker, S.P. Williams, T. Karnezis, R. Shayan, S.B. Fox, M.G. Achen, Lymphangiogenesis and lymphatic vessel remodelling in cancer., Nat. Rev. Cancer. 14 (2014) 159-72. doi:10.1038/nrc3677.

[12] J. Chen, J.S. Alexander, a. W. Orr, Integrins and their extracellular matrix ligands in lymphangiogenesis and lymph node metastasis, Int. J. Cell Biol. 2012 (2012). doi:10.1155/2012/853703. 
[13] E.S. Nakamura, K. Koizumi, M. Kobayashi, I. Saiki, Inhibition of lymphangiogenesis-related properties of murine lymphatic endothelial cells and lymph node metastasis of lung cancer by the matrix metalloproteinase inhibitor MMI270, Cancer Sci. 95 (2004) 25-31.

[14] J. Lin, A.S. Lalani, T.C. Harding, M. Gonzalez, W.W. Wu, B. Luan, et al., Inhibition of lymphogenous metastasis using adeno-associated virus-mediated gene transfer of a soluble VEGFR-3 decoy receptor, Cancer Res. 65 (2005) 6901-6909. doi:10.1158/0008-5472.CAN-05-0408.

[15] D. Dargent, G. Lamblin, P. Romestaing, X. Montbarbon, P. Mathevet, M. Benchaib, Effect of radiotherapy on pelvic lymph node metastasis in cervical cancer stages IB2-IVA: A retrospective analysis of two comparative series, Int. J. Gynecol. Cancer. 15 (2005) 468-474. doi:10.1111/j.1525-1438.2005.15310.x.

[16] M. Hata, I. Koike, H. Wada, Y. Minagawa, T. Kasuya, T. Matsui, et al., Radiation therapy for lymph node metastasis from extramammary Paget's disease, J. Eur. Acad. Dermatology Venereol. 28 (2014) 873-877. doi:10.1111/jdv.12185.

[17] M.T. Ballo, M.D. Bonnen, A.S. Garden, J.N. Myers, J.E. Gershenwald, G.K. Zagars, et al., Adjuvant irradiation for cervical lymph node metastases from melanoma, Cancer. 97 (2003) 1789-1796. doi:10.1002/cncr.11243.

[18] F. Celikoglu, S.I. Celikoglu, E.P. Goldberg, Intratumoural chemotherapy of lung cancer for diagnosis and treatment of draining lymph node metastasis, J. Pharm. Pharmacol. 62 (2010) 287-293. doi:10.1211/jpp/62.03.0001.

[19] G.J. Chang, M. a. Rodriguez-Bigas, J.M. Skibber, V. a. Moyer, Lymph node evaluation and survival after curative resection of colon cancer: Systematic review, J. Natl. Cancer Inst. 99 (2007) 433-441. doi:10.1093/jnci/djk092.

[20] C. Garbe, A. Hauschild, M. Volkenandt, D. Schadendorf, W. Stolz, U. Reinhold, et al., Evidence-based and interdisciplinary consensus-based German guidelines: systemic medical treatment of melanoma in the adjuvant and palliative setting., Melanoma Res. 18 (2008) 152-160. doi:10.1097/CMR.0b013e3282f702bf.

[21] K.K. Giuliano AE Hunt, K. V Ballman, P.D. Beitsch, P.W. Whitworth, P.W. Blumencranz, a M. Leitch, et al., Axillary Dissection vs No Axillary Dissection in Women With Invasive Breast Cancer, Jama. 305 (2011) 569-575. 
[22] K. Taketani, E. Tokunaga, N. Yamashita, K. Tanaka, Y. Zaitsu, S. Akiyoshi, et al., A case of invasive micropapillary carcinoma of the breast involving extensive lymph node metastasis, World J. Surg. Oncol. 12 (2014) 84. doi:10.1186/1477-7819-12-84.

[23] T. Leibold, J. Shia, L. Ruo, B.D. Minsky, T. Akhurst, M.J. Gollub, et al., Prognostic implications of the distribution of lymph node metastases in rectal cancer after neoadjuvant chemoradiotherapy, J. Clin. Oncol. 26 (2008) 2106-2111. doi:10.1200/JCO.2007.12.7704.

[24] J. Kroon, J.M. Metselaar, G. Storm, G. van der Pluijm, Liposomal nanomedicines in the treatment of prostate cancer., Cancer Treat. Rev. 40 (2014) 578-84. doi:10.1016/j.ctrv.2013.10.005.

[25] Y. Li, R. Liu, J. Yang, Y. Shi, G. Ma, Z. Zhang, et al., Enhanced retention and anti-tumor efficacy of liposomes by changing their cellular uptake and pharmacokinetics behavior, Biomaterials. 41 (2015) 1-14. doi:10.1016/j.biomaterials.2014.11.010.

[26] J. Kopeček, Polymer-drug conjugates: Origins, progress to date and future directions, Adv. Drug Deliv. Rev. 65 (2013) 49-59. doi:10.1016/j.addr.2012.10.014.

[27] S. Lv, Z. Tang, D. Zhang, W. Song, M. Li, J. Lin, et al., Well-defined polymer-drug conjugate engineered with redox and $\mathrm{pH}$-sensitive release mechanism for efficient delivery of paclitaxel, J. Control. Release. 194 (2014) 220-227. doi:10.1016/j.jconrel.2014.09.009.

[28] K. Ariga, Y. Yamauchi, G. Rydzek, Q. Ji, Y. Yonamine, K.C.-W. Wu, et al., Layer-by-layer Nanoarchitectonics: Invention, Innovation, and Evolution, Chem. Lett. 43 (2014) 36-68. doi:10.1246/cl.130987.

[29] K. Kataoka, a Harada, Y. Nagasaki, Block copolymer micelles for drug delivery: design, characterization and biological significance., Adv. Drug Deliv. Rev. 47 (2001) 113-131. doi:10.1016/S0169-409X(00)00124-1.

[30] A.Z. Wang, R. Langer, O.C. Farokhzad, Nanoparticle Delivery of Cancer Drugs, Annu. Rev. Med. 63 (2012) 185-198. doi:10.1146/annurev-med-040210-162544.

[31] L. Brannon-Peppas, J.O. Blanchette, Nanoparticle and targeted systems for cancer therapy, Adv. Drug Deliv. Rev. 64 (2012) 206-212. doi:10.1016/j.addr.2012.09.033. 
[32] C. Argyo, V. Weiss, C. Bräuchle, T. Bein, Multifunctional mesoporous silica nanoparticles as a universal platform for drug delivery, Chem. Mater. 26 (2014) 435-451. doi: $10.1021 / \mathrm{cm} 402592 \mathrm{t}$.

[33] X. Cai, J. Hu, J. Xiao, Y. Cheng, Dendrimer and cancer: a patent review (2006 --present), Expert Opin. Ther. Patents. 23 (2013) 515-529. doi:10.1517/13543776.2013.761207.

[34] M. a Mintzer, M.W. Grinstaff, Biomedical applications of dendrimers: a tutorial., Chem. Soc. Rev. 40 (2011) 173-190. doi:10.1039/b901839p.

[35] H. Cabral, K. Kataoka, Progress of drug-loaded polymeric micelles into clinical studies, J. Control. Release. 190 (2014) 465-476. doi:10.1016/j.jconrel.2014.06.042.

[36] M. Rafi, H. Cabral, M.R. Kano, P. Mi, C. Iwata, M. Yashiro, et al., Polymeric micelles incorporating (1,2-diaminocyclohexane)platinum (II) suppress the growth of orthotopic scirrhous gastric tumors and their lymph node metastasis, J. Control. Release. 159 (2012) 189-196. doi:10.1016/j.jconrel.2012.01.038.

[37] H. Cabral, J. Makino, Y. Matsumoto, P. Mi, H. Wu, T. Nomoto, et al., Systemic Targeting of Lymph Node Metastasis through the Blood Vascular System by Using Size-Controlled, ACS Nano. 9 (2015) 4957-4667.

[38] I.B. Oliva, R.M. Coelho, G.G. Barcellos, R. Saldanha-Gama, L.S. Wermelinger, C. Marcinkiewicz, et al., Effect of RGD-disintegrins on melanoma cell growth and metastasis: Involvement of the actin cytoskeleton, FAK and c-Fos, Toxicon. 50 (2007) 1053-1063. doi:10.1016/j.toxicon.2007.07.016.

[39] E. a Murphy, B.K. Majeti, L. a Barnes, M. Makale, S.M. Weis, K. Lutu-Fuga, et al., Nanoparticle-mediated drug delivery to tumor vasculature suppresses metastasis., Proc. Natl. Acad. Sci. U. S. A. 105 (2008) 9343-9348. doi:10.1073/pnas.0803728105.

[40] T. Soszka, K. a Knudsen, L. Beviglia, C. Rossi, a Poggi, S. Niewiarowski, Inhibition of murine melanoma cell-matrix adhesion and experimental metastasis by albolabrin, an RGD-containing peptide isolated from the venom of Trimeresurus albolabris., Exp. Cell Res. 196 (1991) 6-12. doi:10.1016/0014-4827(91)90449-5.

[41] N. Yonenaga, E. Kenjo, T. Asai, A. Tsuruta, K. Shimizu, T. Dewa, et al., RGD-based active targeting of novel polycation liposomes bearing siRNA for cancer treatment, J. Control. Release. 160 (2012) 177-181. doi:10.1016/j.jconrel.2011.10.004. 
[42] P.M. Peiris, R. Toy, E. Doolittle, J. Pansky, A. Abramowski, M. Tam, et al., Imaging metastasis using an integrin-targeting chain-shaped nanoparticle, ACS Nano. 6 (2012) 87838795. doi:10.1021/nn303833p.

[43] J. Kim, H.Y. Nam, J.W. Choi, C.-O. Yun, S.W. Kim, Efficient lung orthotopic tumor-growth suppression of oncolytic adenovirus complexed with RGD-targeted bioreducible polymer., Gene Ther. 21 (2014) 476-83. doi:10.1038/gt.2014.18.

[44] Y. Miura, T. Takenaka, K. Toh, S. Wu, H. Nishihara, M.R. Kano, et al., Cyclic RGD-linked polymeric micelles for targeted delivery of platinum anticancer drugs to glioblastoma through the blood-brain tumor barrier, ACS Nano. 7 (2013) 8583-8592. doi:10.1021/nn402662d.

[45] H. Cabral, N. Nishiyama, S. Okazaki, H. Koyama, K. Kataoka, Preparation and biological properties of dichloro(1,2-diaminocyclohexane)platinum(II) (DACHPt)-loaded polymeric micelles., J. Control. Release. 101 (2005) 223-32. doi:10.1016/j.jconrel.2004.08.022.

[46] K. Shimizu, Y. Higuchi, Y. Kozu, M. Hashida, S. Konishi, Development of a suction device for stabilizing in vivo real-time imaging of murine tissues, J. Biosci. Bioeng. 112 (2011) 508-510. doi:10.1016/j.jbiosc.2011.07.015.

[47] J.S. Desgrosellier, D. a Cheresh, Integrins in cancer: biological implications and therapeutic opportunities., Nat. Rev. Cancer. 10 (2010) 9-22. doi:10.1038/nrc2965.

[48] R.E.B. Seftor, E. a Seftort, K.R. Gehlsent, W.G. Stetler-stevenson, P.D. Brown, E. Ruoslahti, et al., Role of the av $\beta 3$ integrin in human melanoma cell invasion, Proc. Natl. Acad. Sci. U. S. A. 89 (1992) 1557-1561.

[49] S. Kuphal, R. Bauer, A.-K. Bosserhoff, Integrin signaling in malignant melanoma., Cancer Metastasis Rev. 24 (2005) 195-222. doi:10.1007/s10555-005-1572-1.

[50] H. Kikkawa, M. Kaihou, N. Horaguchi, T. Uchida, H. Imafuku, A. Takiguchi, et al., Role of integrin $\alpha v \beta 3$ in the early phase of liver metastasis: PET and IVM analyses, Clin. Exp. Metastasis. 19 (2002) 717-725. doi:10.1023/A:1021356019563.

[51] K. Bauer, C. Mierke, J. Behrens, Expression profiling reveals genes associated with transendothelial migration of tumor cells: A functional role for $\alpha v \beta 3$ integrin, Int. J. Cancer. 121 (2007) 1910-1918. doi:10.1002/ijc.22879. 
[52] E.B. Voura, R. a Ramjeesingh, a M. Montgomery, C.H. Siu, Involvement of integrin alpha(v)beta(3) and cell adhesion molecule L1 in transendothelial migration of melanoma cells., Mol. Biol. Cell. 12 (2001) 2699-2710.

[53] F. Hirschhaeuser, H. Menne, C. Dittfeld, J. West, W. Mueller-Klieser, L. a. Kunz-Schughart, Multicellular tumor spheroids: An underestimated tool is catching up again, J. Biotechnol. 148 (2010) 3-15. doi:10.1016/j.jbiotec.2010.01.012.

[54] P. Parsons-Wingerter, I.M. Kasman, S. Norberg, A. Magnussen, S. Zanivan, A. Rissone, et al., Uniform overexpression and rapid accessibility of alpha5beta1 integrin on blood vessels in tumors., Am. J. Pathol. 167 (2005) 193-211. doi:10.1016/S0002-9440(10)62965-3.

[55] A. Garg, A.W. Tisdale, E. Haidari, E. Kokkoli, Targeting colon cancer cells using PEGylated liposomes modified with a fibronectin-mimetic peptide, Int. J. Pharm. 366 (2009) 201-210. doi:10.1016/j.ijpharm.2008.09.016.

[56] N. Kramer, A. Walzl, C. Unger, M. Rosner, G. Krupitza, M. Hengstschläger, et al., In vitro cell migration and invasion assays, Mutat. Res. Mutat. Res. 752 (2012) 10-24. doi:10.1016/j.mrrev.2012.08.001.

[57] X. Montet, M. Funovics, K. Montet-Abou, R. Weissleder, L. Josephson, Multivalent effects of RGD peptides obtained by nanoparticle display, J. Med. Chem. 49 (2006) 6087-6093. doi:10.1021/jm060515m.

[58] A.R. Reynolds, I.R. Hart, A.R. Watson, J.C. Welti, R.G. Silva, S.D. Robinson, et al., Stimulation of tumor growth and angiogenesis by low concentrations of RGD-mimetic integrin inhibitors., Nat. Med. 15 (2009) 392-400. doi:10.1038/nm.1941.

\section{Acknowledgements}

This study was supported by the Funding Program for World-Leading Innovative R\&D on Science and Technology (FIRST Program) from Japan Society for the Promotion of Science (JSPS), Center of Innovation (COI) Program from Japan Science and Technology Agency (JST), and Takeda Science Foundation. This research is partially supported by the Practical Research for Innovative Cancer Control from Japan Agency for Medical Research and development, AMED, as well as 
Grants-in-Aid for Young Scientists (B; No. 23700526 and No. 25750172 to H.C.; A; No. 24689051 to Y.M.) and Challenging Exploratory Research (No. 24659584 to Y.M.). 


\section{Graphical Abstract}

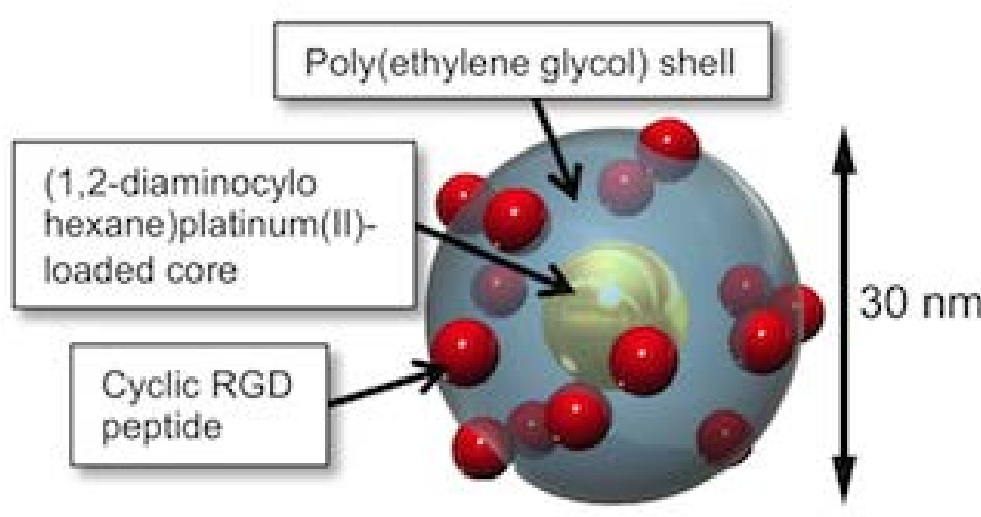

cRGD-installed DACHPt-loaded micelle

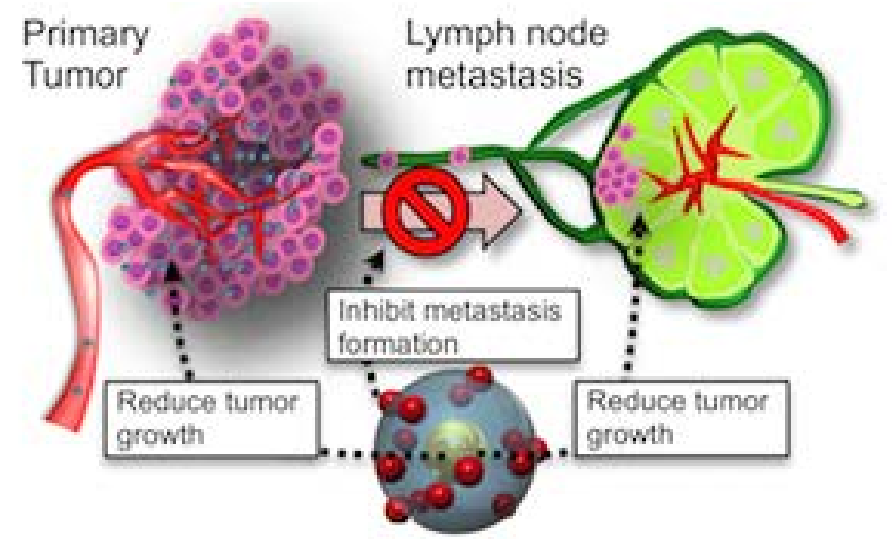

Efficacy of cRGD-installed DACHPt-loaded micelles 